\title{
Experimentally evaluating electrical outputs of a PV-T system in Jordan
}

\author{
Issa Etier ${ }^{1}$, Salem Nijmeh ${ }^{2}$, Mohammed Shdiefat ${ }^{3}$, Omar Al-Obaidy ${ }^{4}$ \\ ${ }^{1}$ Department of Electrical Engineering, Faculty of Engineering, King Abdulaziz University, Rabigh, Kingdom of Saudi \\ Arabia \\ ${ }^{1}$ Department of Electrical Engineering, Faculty of Engineering, Hashemite University, Zarqa, Jordan \\ ${ }^{2,3,4}$ Department of Mechanical Engineering, Faculty of Engineering, Hashemite University, Zarqa, Jordan
}

\begin{tabular}{|c|c|}
\hline Article Info & ABSTRACT \\
\hline Article history: & This experimental work is looking at the properties of photovoltaic/thermal \\
\hline Received Aug 22, 2019 & $\begin{array}{l}\text { (PV-T) system, which had designed to increase the output power of the PV } \\
\text { panel for the climate of Zarga, Jordan. Operating temperature of the PV }\end{array}$ \\
\hline Revised Dec 6, 2020 & module has a significant impact on the performance of the PV module. \\
\hline Accepted Dec 31, 2020 & $\begin{array}{l}\text { However, most of the radiation energy absorbed by the PV panel is converted } \\
\text { into heat, which is normally lost and provides no value. In order to decrease }\end{array}$ \\
\hline Keywords: & $\begin{array}{l}\text { the operating temperature of the PV panel, a water cooling system with a } \\
\text { control system had designed. Experimentally, when the PV module was }\end{array}$ \\
\hline $\begin{array}{l}\text { Photovoltaic/thermal system } \\
\text { Control system }\end{array}$ & $\begin{array}{l}\text { operating under active water-cooling condition using the backside cooling } \\
\text { technique, the temperature dropped significantly, which led to an increase in } \\
\text { the electrical efficiency of solar cells by } 6.86 \% \text {. }\end{array}$ \\
\hline
\end{tabular}

This is an open access article under the $\underline{C C B Y-S A}$ license.

Solar panel

Efficiency of panel

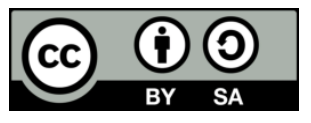

\section{Corresponding Author:}

Issa Etier

Departement of Electrical Engineering

Faculty of Engineering, King Abdulaziz University

Rabigh, Kingdom of Saudi Arabia

Email: ereite@kau.edu.sa

\section{INTRODUCTION}

Jordan is a Middle Eastern country with a population of about 9.5 million inhabitants. It actually does not have commercial quantities of natural resources such as natural gas, crude oil or water, and it only depends on importing gas and oil from other neighbouring Arab countries. However, the combination of the high rates of population-economic growth and the oil prices has increased the annual energy bill. Energy consumption and electricity reached 5828 thousand-ton oil and $16173 \mathrm{GWh}$, respectively. Jordan depends only on fossil fuel for electrical energy generation that generated $18911 \mathrm{GWh}$ of electricity in 2015 , and fossil fuel generated $99.6 \%$ of the generated electricity [1].

Jordan is non-oil producing country, and $97 \%$ of its consumption of natural gas and crude oil are imported that cost 2039 million JD in 2015 [1]. These facts made the government think seriously about involving renewable energy sources. The oil shale and nuclear power into the energy mix in order to achieve an increase in the contribution of the renewable energy from $7 \%$ in 2015 to $10 \%$ in 2020 . Due to the location of Jordan is near to the equator which gives Jordan a good average annual solar radiation equals to about 4.5 $\mathrm{MJ} / \mathrm{m} 2$ [1], [2], so making a renewable energy and energy efficiency law was necessary to achieve significant results from this type of energy through organizing the whole processes that come in common [3]. Figure 1 shows energy mix in Jordan from 2007 to 2020. 


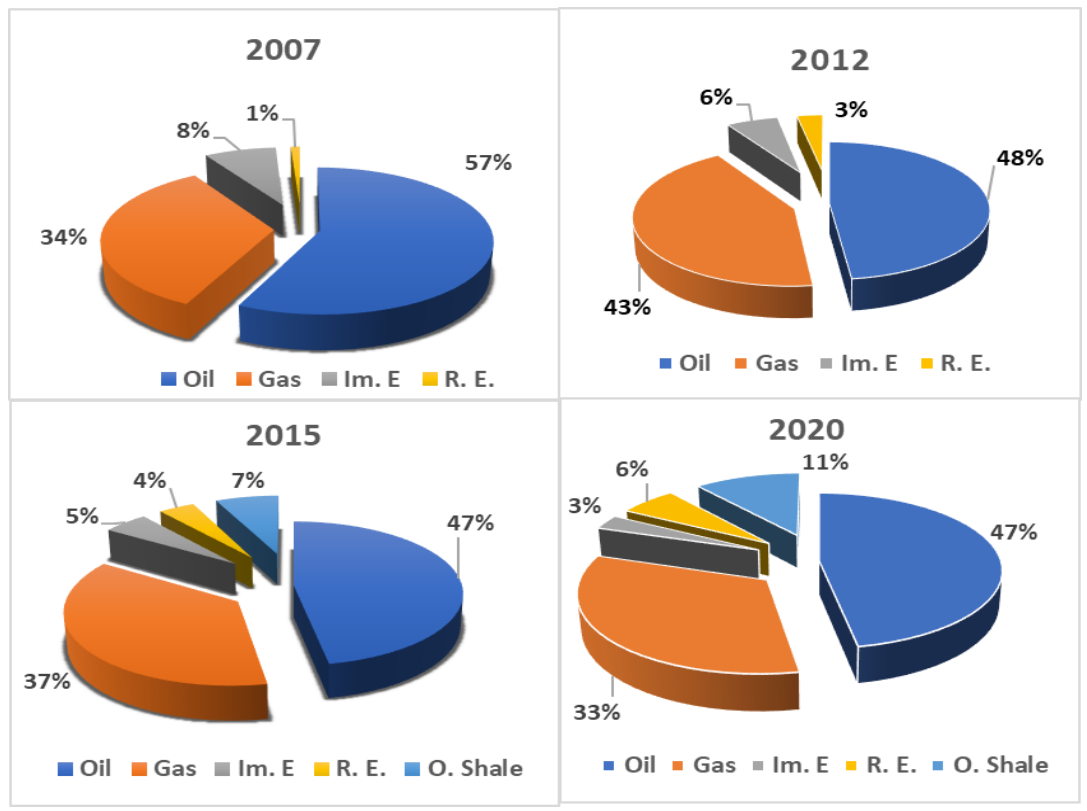

Figure 1. Energy mix in Jordan (2007-2020)

Economic growth and economic consumption perform a relationship, which has treated within economic literature. Renewable energy plays the main role in the economy of most developed and developing countries. Jager-Waldau et al. [4] state the renewable energy as high rate sector compared with the rest of the economy in Europe. Arpegis and Payne [5] found a positive relationship between economic growth and the renewable energy consumption.

Photovoltaic (PV) cells are composed of two or more thin layers of semi-conducting material, but silicon is the common material. The semiconductor will generate electrical charges when it exposed to light, and metal contacts conduct these charges away as direct current (DC). Using multiple cells that are connected together to form a 'string' is necessary because the electrical output from a single cell is small. The most commercially available types of PV cell or film are; monocrystalline, polycrystalline, thick-film and amorphous silicon PV panels.

Renewables in Jordan have the potential to contribute effectively within the electricity provision system. PV system has an unexploited potential, which reduces the greenhouse gas emissions in Jordan significantly. The Jordanian government tries hard to fulfil the convention of the Paris agreement from December 2015 [6].

There is significant growth in the number of solar photovoltaic industries in all over the world. Global Market Outlook for Photovoltaics 2014-2018 [7] presented the recent statistic for the PV sector. According to the report, the excellence in the sector's developments was in 2013. The new installed capacity was about 38.4 gigawatts worldwide in that year. Europe was the leading region with the highest global market installed capacity for a long period, but the position occupied by Asia now, and this happened because of three factors:

1. Great number of China's investment, which led it to be best PV market in the world

2. Japan's Strong investments

3. Breaking in the investments of European continent

As the world needs growth in the generated power of PV panels, there is the need for continuous developments in the PV panels' field to achieve better performance to generate more power with accepted initial costs. One of the developments in the PV system is cooling, which works on the PV cell's temperature to make it down as much as possible. Swapnil Dubey et al. [8] mentioned that the operating temperature of the PV panel plays a role in the conversion process. The output power and the electrical efficiency of the PV panel depend linearly on the operating temperature decreasing with cell's temperature. Griffith et al. [9] found that the rise in the temperature of the PV cell is sensitive to wind speed, less to wind direction while it is insensitive to the atmospheric temperature. On the other hand, it depends on the impinging irradiation i.e., the solar radiation flux on the module or cell [16]. 
Another papers [10] studied cooling the PV cells by using a system called photovoltaic thermal system, which is one of the techniques to cool the operating temperature of the PV module and getting better performance in the generated energy. Both types of research indicated the enhancements in the performance of the cell and mentioned the importance of such systems for the countries of high solar intensity and high ambient temperature.

These papers [11]-[15] discusses aspects of a photovoltaic/thermal (PV-T) system, which designed for cooling the PV system, which leads to an increase in the electrical efficiency of the solar cell.

\section{DESIGN OF THE SYSTEM}

Many PV-T models developed during the last three decades and they can be classified in multiple ways. The main difference is between the flat plate PV-T collectors and the concentrating PV-T collectors. Many papers [16]-[19] compared the energy performance of different PV-T/W (water photovoltaic-thermal) collector design configurations. Computer analysis used to obtain the efficiency curves of nine collector configurations. At zero reduced temperature, the thermal efficiencies of single-glazed and unglazed sheetand-tube collectors found $58 \%$ and $52 \%$, respectively, while the channel-above-PV design is $65 \%$.

Rekstad and Sandnes pasted c-Si solar cells on polymer thermal absorber to develop PV-T/w [20]. The heat absorption was reduced about $10 \%$ of the incident radiation through using the solar cells, while the glazing (if exists) reduced the optical efficiency by $5 \%$. It serves well in a low-temperature water-heating system. Many other papers [21]-[26] studied the back-surface cooling numerically and experimentally and found that there is a good agreement between the numerical results and the experimental measurements performed for the climate of Dhahran, Saudi Arabia. Back surface cooling technique dropped significantly the module temperature to about $20 \%$, which led to an increase in the electrical efficiency of the PV panel by $9 \%$. This research focuses only on the water flat plate collectors and using the backside cooling technique. The following block diagram (Figure 2) shows the processes in the used PV-T system.

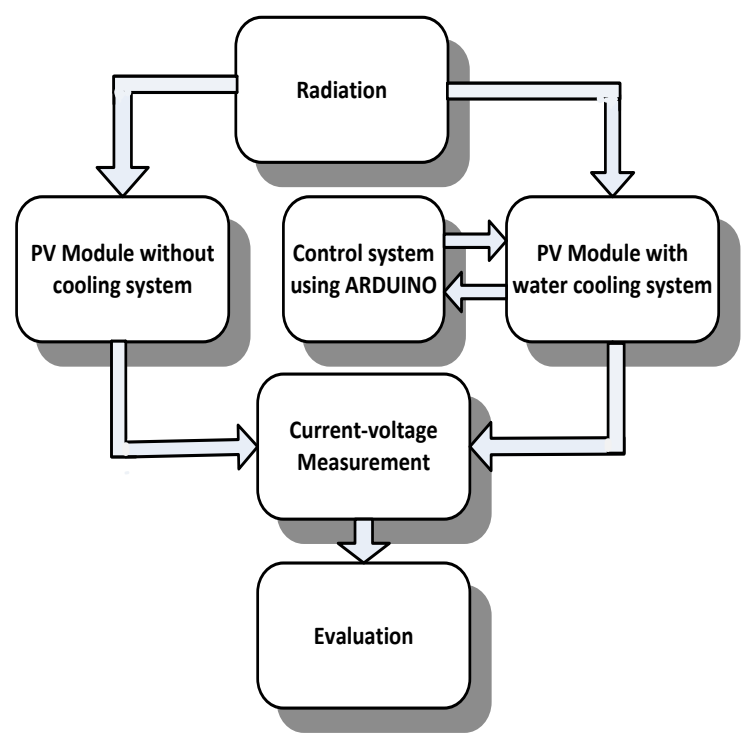

Figure 2. Block diagram of the system with the conventional one

Jordan comes in a region has excellent potential for solar energy generation because it is near the equator with global radiation of $2080 \mathrm{kw} / \mathrm{m}^{2}$ and more than 300 sunny days a year. The experimental study was in Hashemite University, Zarqa, Jordan.

The water cooling system plays the main role in the PV-T system to get the desired improvements in power generation of PV system. The system contained components to build the required system and they are; two solar panels, microcontroller board (Arduino/Genuino), water supply, solenoid valve, level sensor, temperature sensor, thermal resistors and pc device.

One of the PV panels engaged with the water cooling system, while another one used to compare between the PV-T system and the conventional PV system. Figure 3 gives an actual picture for the PV-T system. 


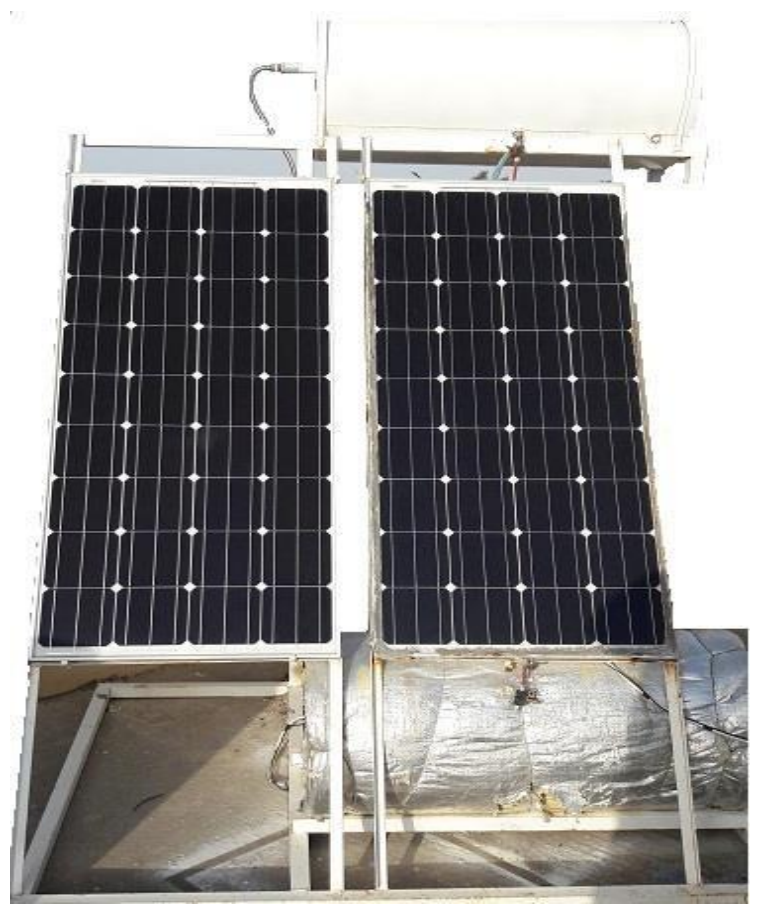

Figure 3. The PV-T system

Microcontroller board is the brain of the system, which controls of all electromechanical parts and reads data; Figure 4 shows the control schematic diagram of the system. Water supply provides us with required water for the cooling process. The solenoid valve controls the water flowing from the water tank to the PV-T system through the data, which provided by the level sensor. The temperature sensor measures the temperature of the water inside the PV-T system. The thermal resistors and pc device are needed for the electrical measurements that are clarified in the methodology section.

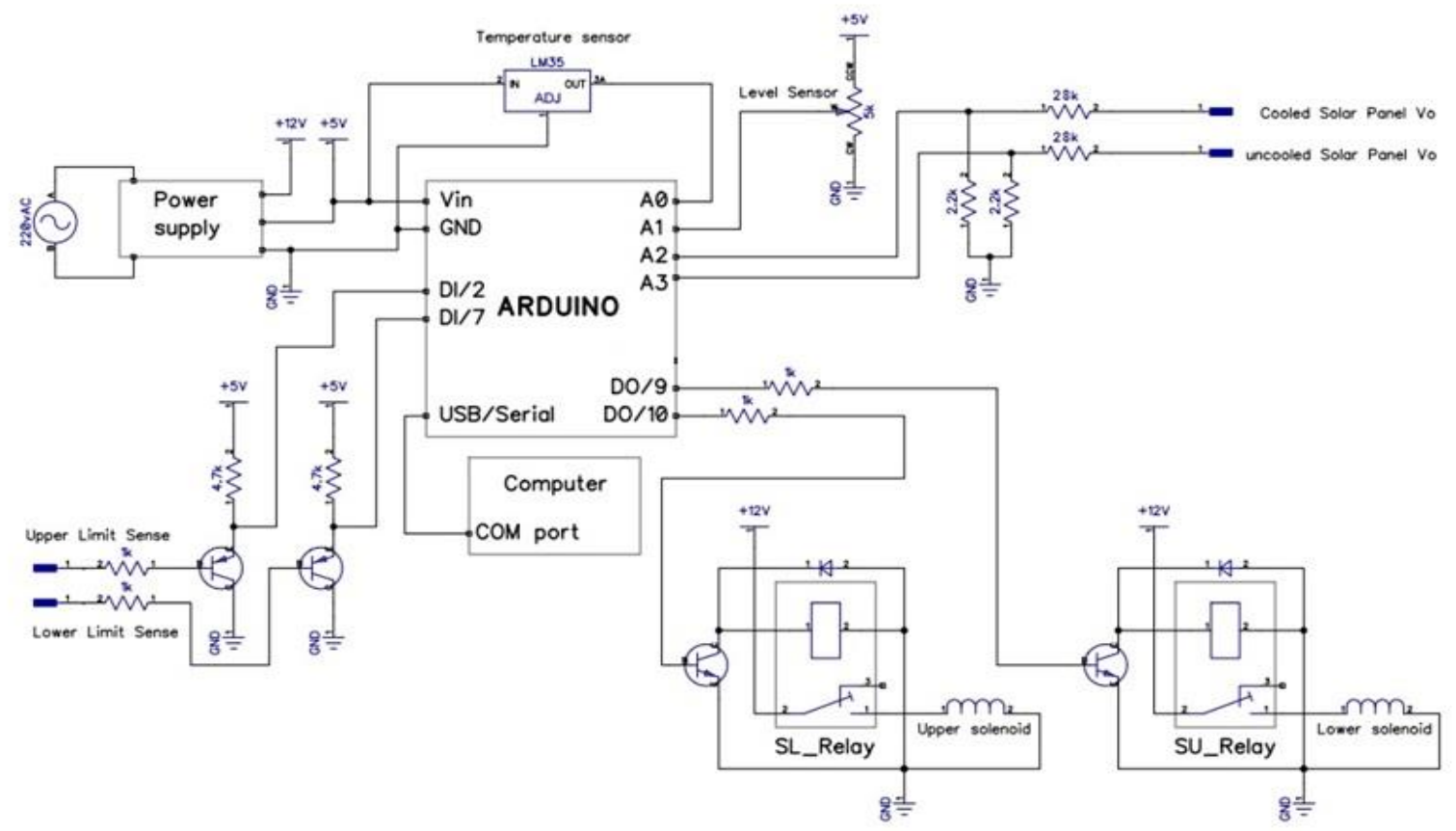

Figure 4. The control schematic diagram of the project 
Electrical measurements were mostly the source of the data that used in studying the behaviour of the PV-T system. As the paper based on experiments, then there were required tools to measure different electrical measurements for the system. Data acquisition board was designed to measure the actual physical readings from the system (temperature and voltage), and to take logical commands based on the data that it receives from the sensors. Multimeter and temperature gun used to check if the voltage and temperature reading flow correctly and give the actual physical situation about the system. The digital Pyranometer and Anemometer used to measure the solar intensity and the wind speed, respectively.

\section{METHOD}

Every system has a method to achieve the desired goals. There are factors should be existed in the method to guarantee smoothness of different processes and getting the desired cooling which can increase the electrical efficiency of the PV-T system, and all that depends on right preparation and connections to the sensors, electromechanical devices and cables with the microcontroller board. Figures 5 shows the flowchart of the processes within the whole system.

Water flows from the feeding water tank to the PV-T system when the upper solenoid valve is open based on an order from the microcontroller. The flowing keeps going until the microcontroller gets a signal from the level sensor indicates that the tank of the PV-T system is full of water, then the microcontroller gives an order to the solenoid valve to be closed. Water in the PV-T system's tank keeps cooling the PV panel through the heat exchange between the water in inside it and the backside of the PV panel. After a period, water reaches to an inefficient temperature for the cooling process; based on that situation the temperature sensor sends a signal to the microcontroller to start discharging the water from the PV-T system's tank by opening the lower solenoid valve.

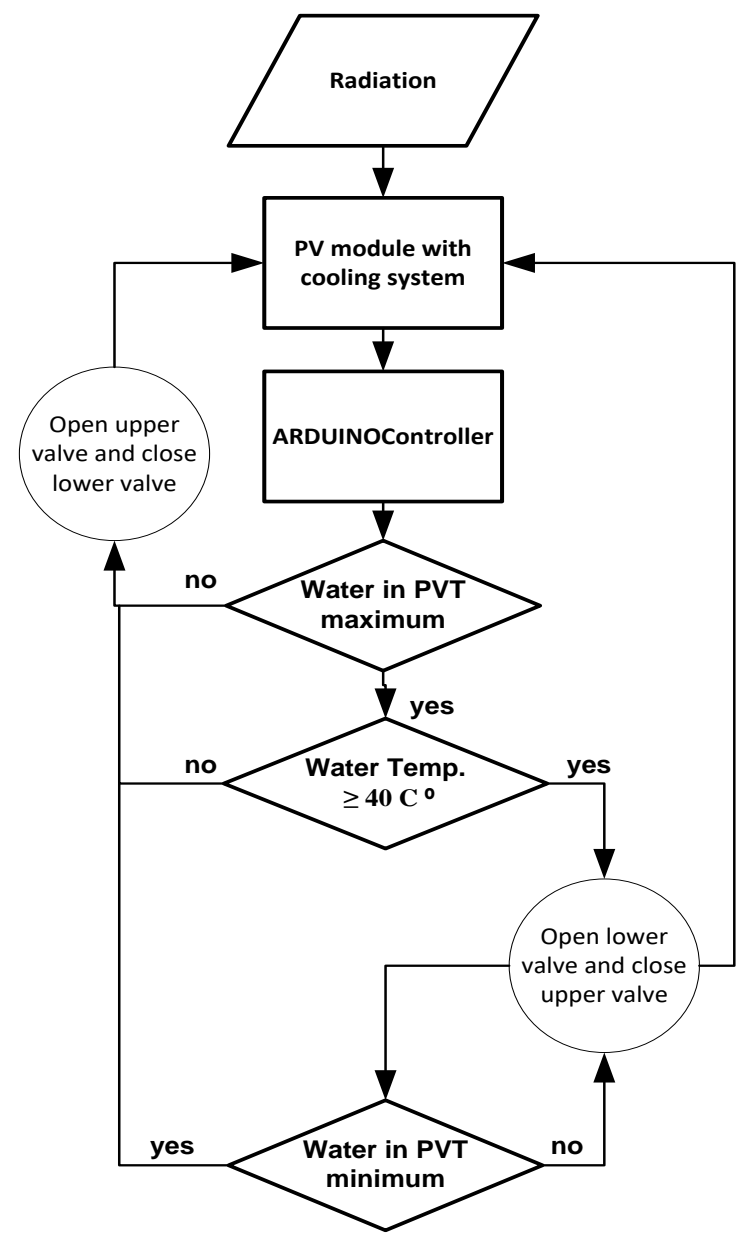

Figure 5. Flowchart of the PV-T system process 


\section{RESULTS AND DISCUSSION}

Electrical performances of the PV-T/w system presented in this paper along with a comparison of different meteorological conditions to investigate the function of the PV-T/w system. The parameters include PV voltage, PV current, electrical efficiency and load. These parameters can give an adequate indication whether the cooling mechanism could make improvements in the electrical performance of the PV-T/W system. Several climatic factors can immensely affect the performance of the PV system such as the ambient temperature, the solar radiation, and the wind speed since the maximum power point tracking curve varies with these factors.

The temperature variation of the module surface (back and front) and the wind speed throughout the test day shown in Figure 6. The maximum temperature of the front surface of the PV-T module was $49{ }^{\circ} \mathrm{C}$, while the maximum temperature of the back surface was $46{ }^{\circ} \mathrm{C}$ at noontime. The average wind speed during the test day was almost $4.5 \mathrm{~m} / \mathrm{s}$.

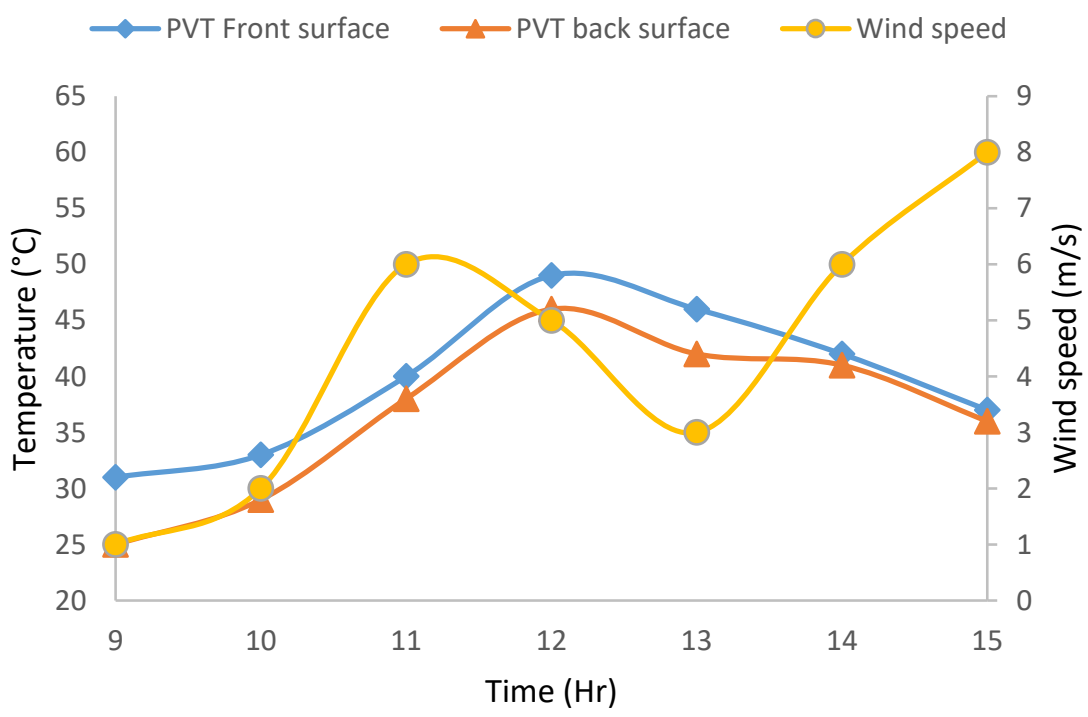

Figure 6. hourly variation of the module temperature (back and front) and the wind speed throughout the test day

PV-T module reduces the high temperature even if the ambient temperature and the irradiation are high. As shown in Figure 7, the maximum PV-T module surface temperature was at noontime, and the temperature reached to $49{ }^{\circ} \mathrm{C}$. This high temperature related to the maximum ambient temperature (which is $31^{\circ} \mathrm{C}$ ) and a high irradiation (which is $690 \mathrm{w} / \mathrm{m} 2$ ).

During the same condition at noontime, the maximum temperature of the conventional panel surface reached $59{ }^{\circ} \mathrm{C}$, and this means that there is $10{ }^{\circ} \mathrm{C}$ difference between the PV-T and the conventional panel surfaces, so the temperature reduction reached to $16.95 \%$ at noontime.

The voltage variation between the two panels decreased if there is high or low ambient temperature. For the high ambient temperature case, the heat exchange between cooling water and panel's surfaces becomes fast which shortens the cooling cycle. For the low ambient temperature case, the impact of the cooling system in the PV-T module becomes lower, because the temperatures of the two panels' surfaces become low. Figure 8 shows the voltages of the panels at different panel temperatures during the test day.

The impact of temperature clearly displayed by the conventional and PV-T panels' I-V (current vs voltage) curve. The different combinations of the current and the voltage that can produced by PV-T and conventional panels under existing conditions shown by I-V curves. Next Figure shows two I-V curves of the conventional and PV-T panels that generated at $690 \mathrm{~W} / \mathrm{m} 2$ of solar intensity. The temperature of the conventional panel was $57^{\circ} \mathrm{C}$, while temperature of the PV-T panel was $40{ }^{\circ} \mathrm{C}$. 


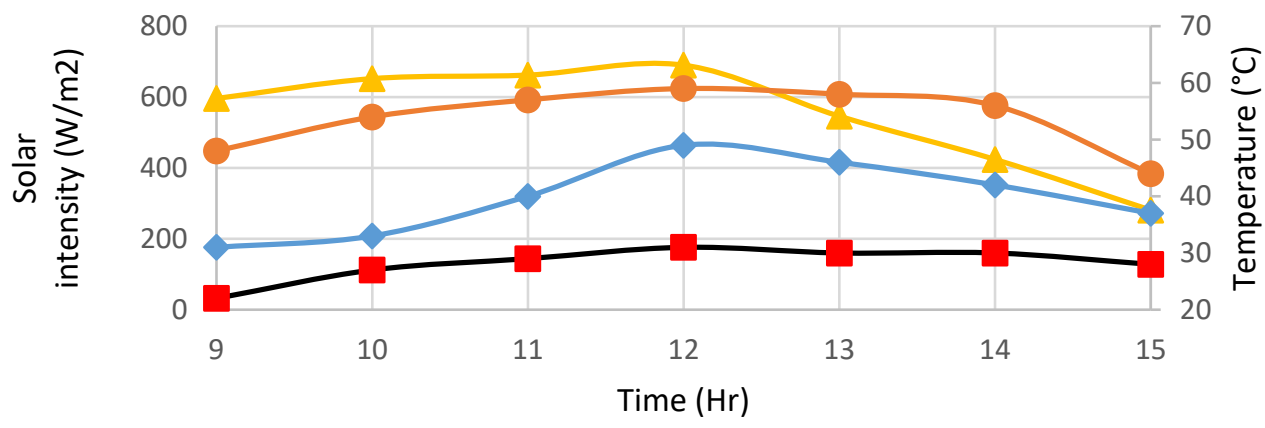

- Irradiation
- Conventional panel surface temperature - Ambient temperature

Figure 7. Variation of panels' surfaces temperatures at different solar intensities and ambient temperatures during the test day

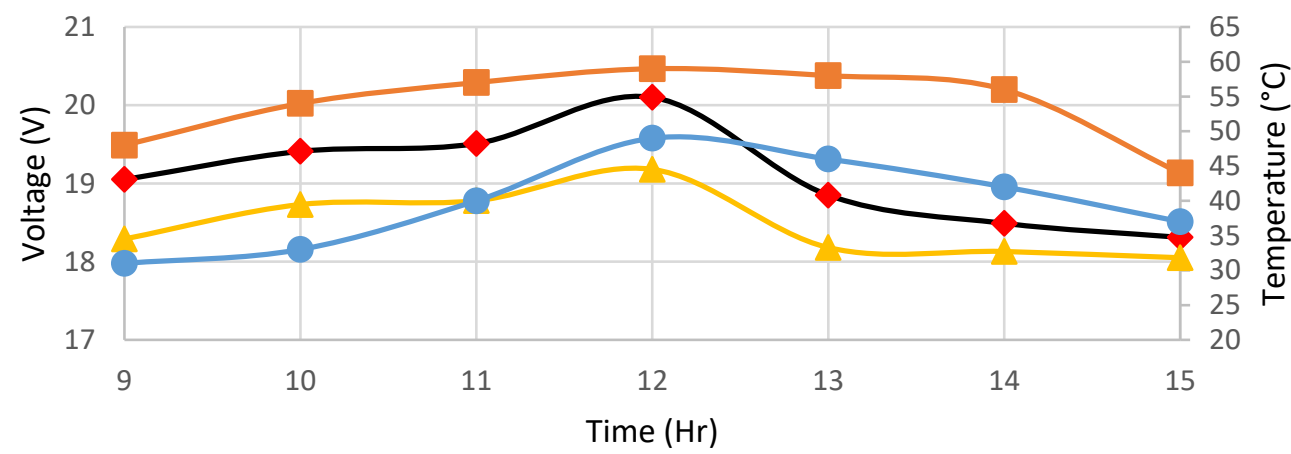

$\longrightarrow$ PVT panel voltage - Cooling
$\longrightarrow$ - Conventional panel voltage

Figure 8. Voltages of PV-T module and the conventional panel with different panel temperatures during test day

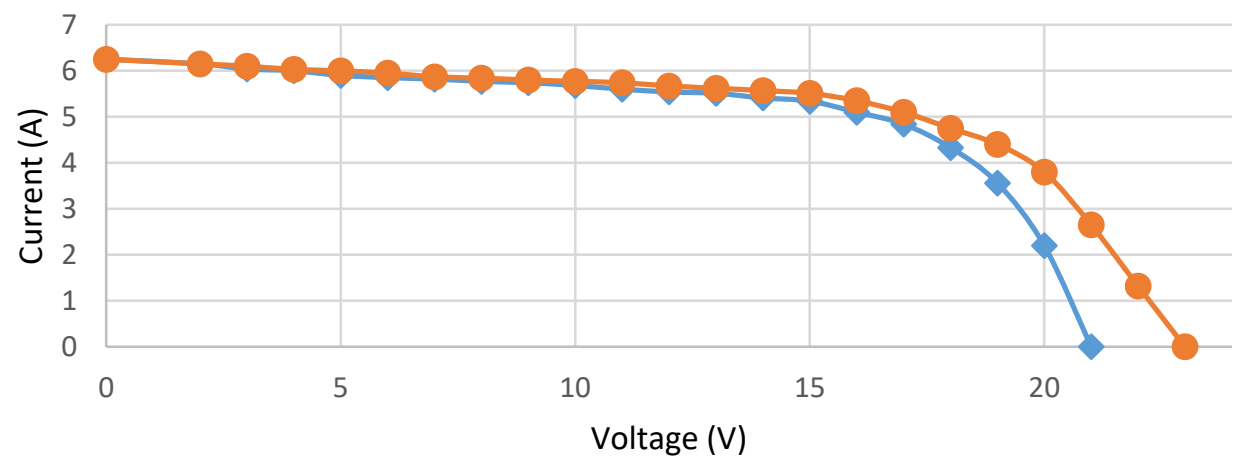

$\smile$ I-V curve of conventional panel $\_$I-V curve of PVT panel

Figure 9. I-V curves of conventional and PV-T panels 
As shown above, it is clear that PV-T panel had a better electrical performance than the conventional panel. There is a clear increase in the open circuit voltage as the temperature decreases, while the short circuit current is almost the same for both panels.

Power is the product of the current and the voltage, so the P-V (power-voltage) curves of the conventional and PV-T panels in Figure 10 can generated by the measured current and voltage. P-V curves show the point where the power is maximum (Pmax). As shown in the figure, there is a small gap in the power between the PV-T module and the conventional PV panel, because of the difference between their operating temperatures. The power of PV-T module reached 85.6 Watt, while the conventional PV panel reached 80.1 Watt producing $6.86 \%$ rise in the electrical power.

The maximum power point tracking (MPPT) gives a clearer view about the difference between the PV-T panel and the conventional panel in power. MPPT is the efficiency of power transfer from the solar cell depending on both the amount of sunlight that incidents on the solar array (solar panels) and the electrical characteristics of the load. As shown in Figure 11, the MPPT of the conventional panel is almost $5.34 \mathrm{~A}$ and $15 \mathrm{~V}$, while the MPPT of the PV-T panel is nearly $5.35 \mathrm{~A}$ and $16 \mathrm{~V}$. Although there is no remarkable difference in the MPPT between the panels, the cooling system on the PV panel keeps showing a positive effect.

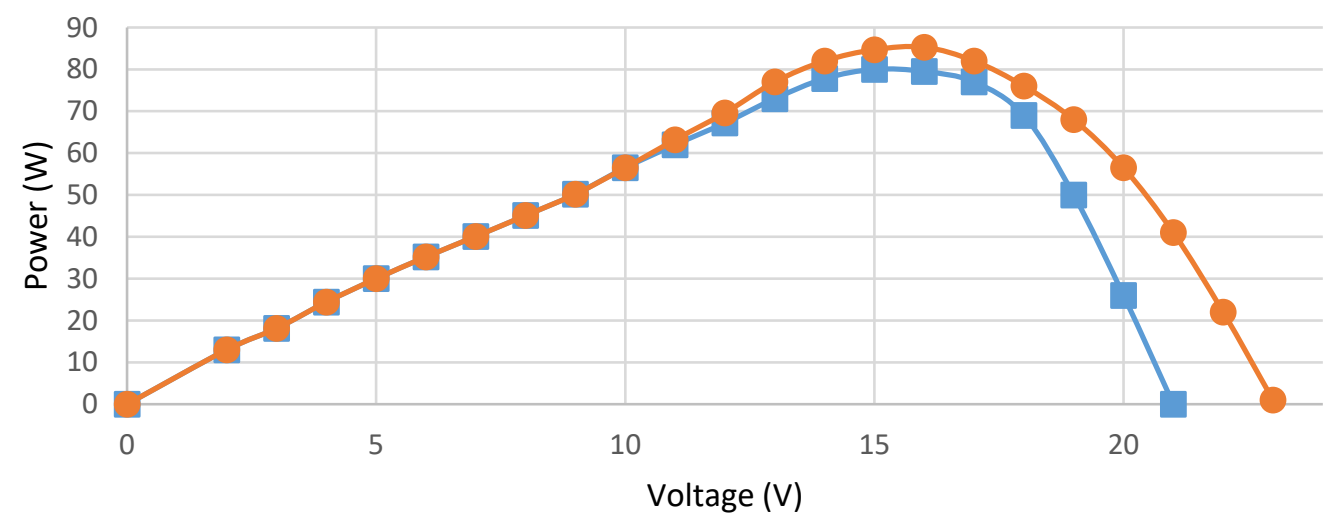

- P-V curve of PVT panel at $40 \mathrm{C}$

Figure 10. P-V curves of conventional and PV-T panels

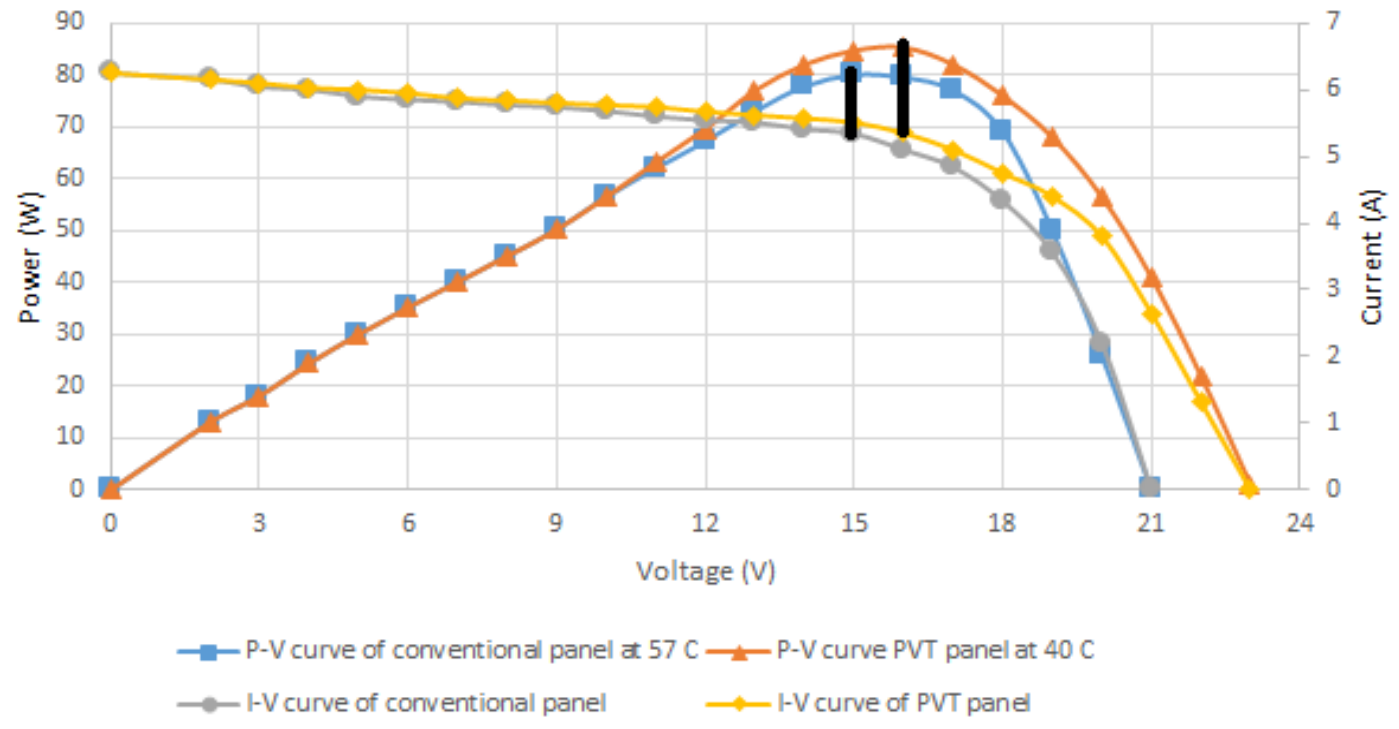

Figure 11. MPPTs of the PV-T and the conventional panels 


\section{CONCLUSION}

The performance of a PV-T system has been successfully determined in an experimental study. The system tested under the climatic conditions of Hashemite University, Jordan. Based on the study, the following tasks and conclusions summarized: A water manifold is fitted backside of the PV panel increased the yielded electrical power. The impact of incorporating a thermal collector with the PV module investigated experimentally. The efficiency of PV panel is sensitive to the panel temperature and it decreases as the panel's temperature increases. The main reasons for a high operating temperature of the PV panel are the conversion of light into electricity and the ambient temperature. Through backside cooling technique, the operating temperature of the module dropped significantly by $26 \%$ and an increase of $6.86 \%$ in the electrical efficiency observed. The control system of the PV-T module organizes the different processes to achieve efficient cooling for the module.

\section{REFERENCES}

[1] The Ministry of energy and Mineral Resources Annual report 2016.

[2] Etier, Issa, Al Tarabsheh, Anas, and Mohammad Ababne, “Analysis of solar radiation in Jordan,” Jordan J Mech Ind Eng., vol. 4, no. 6, pp. 733-737, 2010.

[3] Updated Master Strategy of Energy Sector in Jordan for the period (2007-2020).

[4] Jäger-Waldau, Arnulf, Márta Szabó, Nicolae Scarlat, and Fabio Monforti-Ferrario, "Renewable electricity in Europe," Renewable and Sustainable Energy Reviews, vol. 15, no. 8, pp. 3703-3716, 2011.

[5] Apergis, Nicholas, and James E. Payne. "Renewable energy consumption and economic growth: evidence from a panel of OECD countries," Energy policy, vol. 38, no. 1, pp. 656-660, 2010.

[6] Al-omary, Murad, Martin Kaltschmitt, and Christian Becker, "Electricity system in Jordan: Status \& prospects," Renewable and Sustainable Energy Reviews, 2017.

[7] EPIA European Photovoltaic Industry Association, "Global market outlook for photovoltaics 2014-2018," Brussels, Belgium 60, 2014.

[8] Dubey, Swapnil, Jatin Narotam Sarvaiya, and Bharath Seshadri. "Temperature dependent photovoltaic (PV) efficiency and its effect on PV production in the world - a review," Energy Procedia pp 311- 321,2013

[9] Griffith, John S., Mulchand S. Rathod, and Joel Paslaski. "Some tests of flat plate photovoltaic module cell temperatures in simulated field conditions," In 15th Photovoltaic Specialists Conference, 1981, pp. 822-830.

[10] Al Tarabsheh, Anas, Spyros Voutetakisb, Athanasios I. Papadopoulosb, Panos Seferlisb, Issa Etier, and Omar Saraereha. "Investigation of temperature effects in efficiency improvement of non-uniformly cooled photovoltaic cells," Chemical Engineering Transactions, vol.35, no. 2, pp. 1387-1392, 2013.

[11] Al Tarabsheh, Anas, Issa Etier, Hassan Fath, Abduallah Ghazal, Yousef Morci, Mohamed Asad, and Amgad El Haj. "Performance of photovoltaic cells in photovoltaic thermal (PVT) modules," IET Renewable Power Generation, vol. 10, no. 7, pp. 1017-1023, 2016.

[12] Ahmad Fudholi, Nur Farhana Mohd Razali, Abrar Ridwan, Rado Yendra, Hartono, Ari Pani Desvina, Majid Khan Bin Majahar Ali, Kamaruzzaman Sopian, "Overview of Photovoltaic Thermal (PVT) Water Collector," International Journal of Power Electronics and Drive System (IJPEDS), vol. 9, no.4, pp. 1891-1898, 2018.

[13] S. Singh, S. Agrawal, D. V. Avasthi and A. Saraswat, "Electrical energy analysis and optimization of single pass unglazed PVT system using evolutionary algorithm," 2015 1st International Conference on Next Generation Computing Technologies (NGCT), Dehradun, 2015, pp. 814-819, doi: 10.1109/NGCT.2015.7375233.

[14] F. Leonforte, C. Del Pero, N. Aste, A. Miglioli, L. Croci and G. Besagni, "Energy assessment and monitoring of a novel photovoltaic-thermal collector designed for solar-assisted heat pump systems," in IET Renewable Power Generation, vol. 14, no. 13, pp. 2323-2330, 510 2020, doi: 10.1049/iet-rpg.2020.0108.

[15] Ahmad Fudholi, Muhammad Zohri, Ivan Taslim, Merita Ayu Indrianti, Intan Noviantari Manyoe, "Theoretical approach model of building integrated photovoltaic thermal air collector," International Journal of Power Electronics and Drive System (IJPEDS), vol. 11, no. 2, pp. 1002 1010, 2020.

[16] H. A. Zondag, D. W. de Vries, W. G. J. van Helden, R. J. C. van Zolingen, and A. A. van Steenhoven, "The thermal and electrical yield of a PV-thermal collector," Solar Energy, vol. 72, no. 2, pp. 113-128, 2002.

[17] H. A. Zondag, D. W. de Vries, W. G. J. van Helden, R. J. C. van Zolingen, and A. A. van Steenhoven, "The yield of different combined PV-thermal collector designs," Solar Energy, vol. 74, no. 3, pp. 253-269, 2003.

[18] Adnan Ibrahim, Sohif Mat, Ahmad Fazlizan Abdullah, Ahmad Fudholi, Kamaruzzaman Sopian, "Outdoor Performance Evaluation of Building Integrated Photovoltaic Thermal (BIPVT) Solar Collector with Spiral Flow AbsorberConfigurations," International Journal of Power Electronics and Drive System (IJPEDS), vol. 9, no. 4, pp. 1918-1925, 2018.

[19] S. Singh, R. K. Singh and G. N. Tiwari, "Effect of Oscillatory Water Flow on the Performance of Photovoltaic Thermal System in Summer Condition," 2018 International Conference on Computational and Characterization Techniques in Engineering \& Sciences (CCTES), Lucknow, India, 2018, pp. 221-226, doi: 10.1109/CCTES.2018.8674075.

[20] B. Sandnes and J. Rekstad, "A photovoltaic/thermal (PV/T) collector with a polymer absorber plate. Experimental study and analytical model," Solar Energy, vol. 72, no. 1, pp. 63-73, 2002

[21] Bahaidarah, H., Abdul Subhan, P. Gandhidasan, and S. Rehman. "Performance evaluation of a PV (photovoltaic) module by back surface water cooling for hot climatic conditions," Energy, vol. 59, pp. 445-453, 2013.

[22] Junghoon Lee, Seong Baeg Kim, Gyung-Leen Park, "Data Analysis for Solar Energy Generation in a University 
Microgrid," International Journal of Electrical and Computer Engineering (IJECE), vol. 8, no. 3, pp. 1324-1330, 2018.

[23] G. N. Tiwari and A. Gaur, "Photovoltaic thermal (PVT) systems and its applications," 2nd International Conference on Green Energy and Technology, Dhaka, 2014, pp. 132-138, doi: 10.1109/ICGET.2014.6966678.

[24] A. Hazi, R. Grigore and G. Hazi, "Energy efficiency of the PVT system used in industry," 2012 11th International Conference on Environment and Electrical Engineering, Venice, 2012, pp. 235-240, doi: 10.1109/EEEIC.2012.6221579.

[25] Benabed Khadidja, Boudghene Stambouli Amine, Benabadji Noureddine, "Control and supervision of a solar electric system,” International Journal of Power Electronics and Drive System (IJPEDS), Vol. 10, No. 4, pp. 20962100,2019 ,

[26] Othmane Salama, Abdelmoumen Tabyaoui, Mohamed Benchagra, "Control Methods on Three-phase Power Converters in Photovoltaic Systems," International Journal of Power Electronics and Drive System (IJPEDS), vol. 9, no.4, pp. 1851-1865, 2018.

\section{BIOGRAPHIES OF AUTHORS}
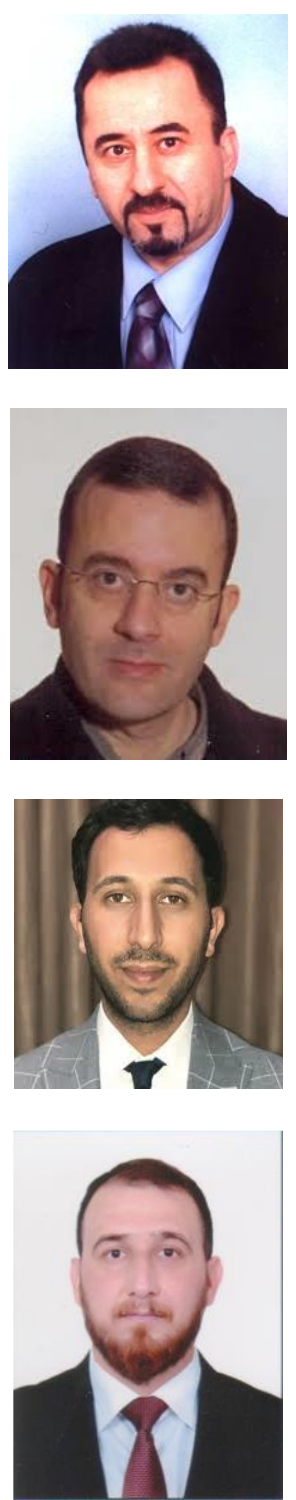

Issa Etier was born in Ramtha, Jordan He received his Master's and $\mathrm{Ph}$. D. Degrees in Electrical Eng. in Institute of Energy and Automation Technology from T. U. Berlin in 1996 and 2005. His research interests include Renewable Energy systems, Energy conversion and Photovoltaic Systems.

Salem Nijmeh was born in Amman, Jordan He received his Ph D. Degree in Mechanical Eng. from the University of Reading, U.K. His research interests include Renewable Energy and HVAC systems.

Mohammad Al Shdaifat was born in AL Mafraq, Jordan He received his bachelor's and Master's Degrees in mechanical Eng. And energy systems in Institute of Mechanical engineering from Hashemite University Zarqa in 2014 and 2017. His research interests include Energy systems, Energy conversion and biomass systems.

Omar khalid shihab Al-Obaidy was born in Baghdad iraq. He received his master's degree in mechanical Engineering/Energy systems from The Hashemite university zarqa_jordan in 20, April, 2017.His research interests include energy systems 